\title{
The Influence of a Science Methods Course on Prospective Elementary Teachers' Visions of Science Teaching
}

\author{
Martha M. Canipe, PhD \\ Northern Arizona University, Flagstaff, Arizona, United States \\ (iD https://orcid.org/0000-0001-6721-0908 \\ Jessica Y. Coronado Verdugo \\ Northern Arizona University, Flagstaff, Arizona, United States
}

Contact: marti.canipe@nau.edu

\begin{abstract}
Prospective elementary teachers may enter their teacher education program having experienced science more as a collection of definitions and facts than in ways that support rich engagement with scientific phenomena. As a result, their visions of themselves as science teachers may not align with the most recent understandings about how to teach science to support student learning. Science methods courses are settings that have the potential to shift prospective teachers' visions of science teaching. We used an explanatory sequential mixed methods approach with collection of survey data followed by interviews with selected participants. We analyzed how prospective elementary teachers' visions of science teaching shifted over the course of a onesemester science methods course and what experiences they felt most influenced their visions of teaching science. We found that the visions of science teaching shifted towards or maintained alignment with the principles of science teaching introduced in the science methods course. Additionally, the prospective teachers identified model science activities and explicit connections between these activities and how students learn science as having influenced them in terms of how they thought about teaching science.
\end{abstract}

Keywords: prospective elementary teachers; science teacher education; teacher identity

Date Submitted: April 6, 2020 | Date Published: September 23, 2020

\section{Recommended Citation}

Canipe, M. M., \& Coronado Verdugo, J. Y. (2020). The influence of a science methods course on prospective elementary teachers' visions of science teaching. Journal of Educational Research and Practice, 10, 299-316. https://doi.org/10.5590/JERAP.2020.10.1.19

\section{The Influence of a Science Methods Course on Prospective Elementary Teachers' Visions of Science Teaching}

Despite recognition of the importance of students having high-quality science experiences throughout elementary school (National Research Council, 2007), many elementary schools across the United States do not spend much time teaching science (Plumley, 2019). Furthermore, the amount of time spent teaching science has declined since the early 1990s (Blank, 2013). Decreased time spent teaching science is of 
particular concern for elementary science teacher educators because many current undergraduate students who are prospective elementary teachers were elementary students during this time of declining science instruction. Additionally, when science was taught in elementary schools, it was often presented as a collection of vocabulary and facts (Banilower et al., 2013) rather than in ways that engaged students in the practices of science (National Research Council, 2012). Together, these factors may contribute to a disconnect between what prospective elementary teachers learn about teaching science in their university coursework, their own experiences as learners of science, and what they might observe in school settings (Luehmann, 2007). This disconnect can lead prospective teachers to adopt approaches to teaching science other than the research-based approaches introduced in their teacher preparation programs (Boyer, 2016). Therefore, it is important to understand what experiences during teacher education are particularly impactful for prospective teachers as they develop their visions of teaching science.

One of the enduring dilemmas of teacher education is the tension between content specific and more general pedagogical approaches (Richmond et al., 2018; Schneider, 2018). Furthermore, a focus on developing pedagogical knowledge, both content specific (such as how to teach about magnetism) as well as more general (such as how to assess student learning), has been identified as one of the areas that drives change in teacher education (Floden et al., 2020). Furthermore, elementary teachers are expected to be generalists who teach all content areas rather than being able to specialize in developing knowledge for only one subject area. In light of this focus and accompanying tension, this study examined how prospective elementary teachers' views of science teaching shifted from the beginning to the end of a science methods course and what experiences they perceived as impactful in developing their visions of science teaching.

\section{Literature Review}

There is a long-held axiom that teachers' beliefs form early and are resistant to change. However, changes in prospective elementary teachers' educational beliefs during their teacher preparation have been documented (Wall, 2016). Overall, this shift was characterized as moving from an idealistic view of a teacher's role to a more realistic view of a teacher's role. This vision moved through stages from learning to think like a teacher to learning to feel like a teacher. Soysal and Radmond (2018) found that a teacher education program which engaged prospective elementary and secondary teachers in social co-constructivist teaching activities which involved "posing-recognizing contradictions, [and] negotiating-resolving contradictions." (p. 62), led to prospective teachers shifting towards more sophisticated and learner-centered views of teaching. This shift moved the prospective teachers from primarily teacher-centered views towards those that included teachercentered and learner-centered elements. Both of these studies found that prospective teachers' beliefs can be shaped by experiences in teacher preparation programs and raise questions about the role that specific courses might have in shaping prospective teacher beliefs. In particular, this study sought to understand the role of an elementary science methods course.

\section{Experiences With Science and Science Teaching}

Research shows that prospective elementary teachers' prior experiences with science either in a methods course or in a science content course impact their thinking about science teaching. For example, two beginning elementary teachers who employed inquiry-based teaching practices identified their experiences during their teacher preparation program as influential to the development of these teaching practices (Avraamidou \& Zembal-Saul, 2010). Research in this area underscores the important role prospective teachers' prior experiences with science as a discipline play relating to their becoming teachers of science. Prospective teachers who experienced an inquiry-oriented science course had more positive views towards inquiry in teaching science (Haefner \& Zembal-Saul, 2004), and, similarly, prospective teachers who experienced an inquiry-focused methods course recognized the importance of inquiry-based experiences for their future students (Varma et al., 2009). 
In addition to university course experiences, teacher education programs offer prospective teachers opportunities to work with students and practicing teachers through field placements. In these field placements, prospective elementary teachers often have few opportunities to observe and teach science, but students valued them when they were available (Blackmore et al., 2018). These prospective teachers initially lacked confidence to teach science, but over time this improved. The improvement, however, was linked to university experiences rather than classroom experiences (Blackmore et al.). This illustrates why teacher educators should consider the experiences that students have in their methods courses.

One teacher education practice shown to be effective across multiple content areas is modeling (McGrew et al., 2018). In order for modeling to be an effective practice, the teacher educator must not only demonstrate pedagogical moves, but must also explain the pedagogical reasoning that undergirds them (McGrew et al.). The science methods course that the participants in this study took featured the practice of modeling as a primary practice. Beyond understanding the practicalities of how to teach science, development of students' self-efficacy beliefs and confidence may impact prospective teachers when it comes to teaching science.

\section{Self-efficacy and Confidence}

In previous research with prospective elementary teachers, we found that the desire to be a good science teacher was sometimes tempered with nervousness about what it meant to be a good science teacher (Canipe, 2016). Earlier studies showed that prospective elementary teachers' previous experiences with learning science and their confidence in their own abilities to teach science impact their views of teaching science. Those prospective teachers who had positive experiences with science expressed more self-efficacy about being a teacher of science (Bleicher \& Lindgren, 2005; Tosun, 2000a). However, prospective teachers who used negative descriptors about science expressed a lower level of self-efficacy even when they had been successful science students (Tosun).

Furthermore, prospective elementary teachers often enter their methods courses with generally high selfefficacy beliefs even before they have any formal instruction about teaching methods for science (Settlage et al., 2009). The fact that many prospective teachers have high self-efficacy beliefs at a point in their preparation program when they have minimal experience teaching science raises important questions about how they view teaching science. Schwarz et al. (2008) found that many prospective elementary teachers viewed "making science fun" (p. 365) as a goal for teaching science. Confidence in their ability to provide students with fun experiences could contribute to high self-efficacy beliefs that prospective elementary teachers have prior to formal experience or instruction with regards to science teaching. Additionally, science methods courses have generally been shown to have positive impacts on prospective elementary teachers' selfefficacy beliefs (Bleicher \& Lindgren, 2005; Palmer, 2006; Tosun, 200ob) and attitudes (Murphy \& Smith, 2012; Varma et al., 2009) in regards to teaching science.

Focusing on prospective elementary teachers' self-efficacy and/or confidence about teaching science may provide an incomplete picture of how prepared prospective teachers are to teach science. In fact, measures of prospective elementary teachers' confidence may be inconsistent with their knowledge and skills about what is actually needed to support student learning (Settlage et al., 2009). Also, while previous experiences learning science and science methods courses have been shown to be important as prospective elementary teachers become teachers of science, this research has not fully explored how these experiences impact prospective elementary teachers' visions of themselves as teachers of science.

\section{Visions of Science Teaching}

Some researchers suggested that it is critically important that new teachers are able to develop their identity as teachers of science and that teacher educators should consider prospective teachers' identity development as part of preparing science teachers (Davis et al., 2006; Luehmann, 2007). By focusing on identity 
development, researchers can move beyond a perspective that is focused solely on skills, beliefs, or knowledge (Luehmann) and towards understanding how prospective elementary teachers see themselves as science teachers. Being able to envision oneself as a science teacher is an important part of becoming a science teacher (Davis et al.), and an individual's identity as a teacher impacts how they act as a teacher as well as their understanding of what it means to be a teacher (Sachs, 2005). Furthermore, it has been suggested that having a vision of what effective science teaching looks like and understanding the critical components of this vision are crucial to becoming an effective science teacher (Banilower, 2019). This focus on identity work as part of teacher education should be considered in conjunction with knowledge growth rather than as an alternative (Smith, 2007).

\section{Research Questions}

If elementary science education is to be improved so that it engages students in the practices of science (National Research Council, 2012) rather than presenting scientific knowledge as a collection of vocabulary and facts, elementary science teacher educators must consider how prospective elementary teachers make sense of their teacher education experiences. In particular more understanding is needed about prospective elementary teachers' visions of science teaching and what experiences are most impactful in relation to these visions. Therefore this study aimed to answer the following research questions:

1. In what ways, if any, do prospective elementary teachers' visions of science teaching shift over the course of a semester-long science methods course?

2. What experiences during the methods semester are perceived by prospective elementary teachers as influencing their visions of science teaching?

\section{Methods}

This explanatory sequential mixed methods (Creswell \& Clark, 2017) study used pre-/post-surveys and followup interviews to explore the shift in prospective elementary teachers' visions of science teaching and which experiences the prospective elementary teachers perceived as influencing those visions.

\section{Participants}

The participants in this study were 171 undergraduate students enrolled in an elementary science methods course between Fall 2016 and Fall 2019 taught by the first author. At a minimum all participants were pursuing certification as elementary teachers. In addition, some participants were also pursuing an early childhood endorsement or special education certification as well. In this teacher preparation program, content specific methods courses were spread over three semesters. During each methods semester, prospective teachers were concurrently enrolled in a field placement practicum where they spent a minimum of 3 hours per week in a classroom working with a mentor teacher. The science methods course took place during the second methods semester. Following the third semester of methods, students completed a semester-long student teaching experience prior to graduation.

\section{Context-Science Methods Course}

The science methods course was designed around several key principles of teaching science. These key ideas included "experiences before explanations" (Gunckel, 2010), eliciting and using student ideas (Windschitl et al., 2012), recognizing students' funds of knowledge (Gonzalez et al., 2005) and using them to plan science instruction, and using the Inquiry-Application Instructional Model (I-AIM) to plan science lessons (Gunckel, 
2011). This inquiry-based model emphasized eliciting and using students' ideas and engaging students in the practices of science and engineering (National Research Council, 2012).

During the semester, students participated in model activities and lessons that demonstrated the principles introduced in the course and then explored how these activities were framed using a particular principle of science education. For example, students investigated the question, "How strong is a bag of air?" by trying to lift objects by blowing through a straw into a plastic bag placed under the object. Once the data were collected, students made a claim about the strength of air supported by the evidence they gathered during the investigation. Students then watched a video (Zembal-Saul et al., 2013) of third and fourth graders doing the same activity and discussed the pedagogical moves made by the teacher in the video and their methods course instructor.

Additionally, over the course of the semester, students implemented two science activities in their field placement classrooms. The first of these was a science talk (Gallas, 1995) that occurred during the first half of the semester. The second was to plan and teach a science lesson towards the end of the semester. Students were supported in the planning process for both of these activities as part of the methods course.

\section{Data Collection}

The data for this study were collected with two surveys completed by all participants and from follow-up interviews conducted with selected participants. Each of these data sources is described below.

\section{Visions of science teaching survey}

This survey was based on a card sort activity developed by Friedrichsen and Dana (2003), which was intended to elicit teachers' science-teaching orientations. The survey presented 20 short science-teaching scenarios (see Table 1) and asked participants to identify if the scenario described a way in which they would teach science "definitely, sometimes, or never." The scenarios used in the survey were adapted from the card sort activity and designed to include ways that prospective teachers might have seen science being taught as well as ways that aligned with the principles introduced in the science methods course. As designed, this survey was not intended to produce a score that could be used to classify teachers as a certain "type" of science teacher. Rather, it was used to elicit teachers' views of particular ways of teaching science. In this study it was used to make comparisons in these views before and after a science methods course. Therefore, the survey was administered online during the first week of the semester and in-person during the last class meeting for the semester.

\section{Science biography survey}

At the beginning of the semester participants completed an online survey about their past experiences with science. This survey asked participants to describe their feelings about science in elementary, middle, and high school as well as college; a memorable science learning experience; what science courses they had taken in college; how they felt about teaching elementary school science; and what they wanted to learn about teaching elementary school science.

\section{Interviews}

Additionally, some participants were invited to participate in follow-up interviews after the completion of their science methods course. The criteria used to select participants for follow-up interviews were those who described very positive or very negative feelings about science in the Science Biography Survey and/or students whose ratings of teaching scenarios on the Visions of Science Teaching Survey changed a great deal or very little from the beginning to the end of the semester based on the pre/post Visions of Science Teaching surveys. In total, 32 participants completed follow-up interviews. 
The goal of the interviews was to identify experiences that the prospective teachers perceived as particularly influential in relation to their vision of themselves as science teachers. As part of the interview, participants were presented with teaching scenarios where their responses changed between definitely and never or stayed the same between the pre- and post-surveys and asked if they could explain why their response changed or stayed the same. Interviewers also asked participants about particular experiences or assignments during the methods course that they felt were particularly influential about how they thought about science teaching. Participants also identified experiences that were not part of the methods course that they felt influenced how they thought about teaching science. Additionally, participants reviewed their responses to the Science Biography Survey question, "How do you feel about teaching elementary school science?" and were then asked how they would answer that question at this point, after completing the science methods course.

\section{Data Analysis}

We converted the Visions of Science Teaching survey responses to numerical values (definitely = 3; sometimes $=2$; and never $=1$ ) and analyzed the data using the Wilcoxon signed-rank test (Woolson, 2008) in SPSS to determine if there were significant differences between the pre-/post-surveys. Seven participants failed to complete one of the surveys. In the analyses, we excluded these unpaired data on a case-wise basis.

We used qualitative analysis techniques to analyze the data from the Science Biography Survey responses and follow-up interviews. The analysis of the surveys began with thematic coding (Marshall \& Rossman, 2010) focused on whether participants described their past science experiences positively, negatively, or mixed. Similar thematic coding was used to analyze how participants described their feelings about teaching elementary school science with an additional code added for participants who described feeling anxious or nervous. We transcribed the follow-up interviews and open-coded to develop themes in participant responses (Saldaña, 2016). Both authors independently coded two surveys and two interviews and interrater reliability was found to be $94 \%$. The second author then completed coding of the remaining surveys and interviews.

After coding was completed, we constructed analytic memos (Emerson et al., 1995) for each participant. The purpose of these memos was to look for patterns across all data sources for each participant. These patterns supported the validity of claims that were made using the process of triangulation in which multiple sources of data are used to support a claim (Marshall \& Rossman, 2010). In addition to analytic memos for each participant, we also wrote memos for each interview question to look for themes across participants' responses to the same question. This was particularly useful to identify those experiences that multiple participants described as influencing their vision of science teaching.

\section{Positionality}

The first author of this paper was the instructor of the science methods course providing the context of the study. Potential bias that might arise as a result of this relationship with the participants was mitigated in several ways. First, while recruitment for study participants occurred in the course the recruitment and consent process was conducted by a third party who kept the consent forms until after the instructor submitted final course grades. In this way the instructor had no way of knowing which students consented and which did not until they were no longer her students. Second, the Science Biography Survey and Visions of Science Teaching Survey were regular course assignments that all students completed whether or not they were participants in the study. Students completed the follow-up interviews the semester after students took the science methods course. Finally, the second author or a graduate research assistant conducted the majority (84\%) of the follow-up interviews. 


\section{Findings}

In this section, we first present the quantitative results from the Visions of Science Teaching survey that was administered at the beginning and end of the science methods course. A summary of these results can be found in Table 1. This is followed by the qualitative results from the follow-up interviews conducted after the methods course.

\section{Alignment With Visions of Science Teaching From Science Methods Course}

One of the key principles for teaching science introduced during the science methods course was that students have experiences with scientific phenomena, look for patterns in those experiences, and then be introduced to scientific explanations of these phenomena (Gunckel, 2010). This principle was summarized as "experiences before explanations," and the course instructor (first author) emphasized it as the key idea of the course. One of the practical implications of this principle is that scientific vocabulary and the accompanying definitions should be introduced after experiences so that students have an experience they can connect to the vocabulary term. Several of the scenarios on the Visions of Science Teaching Survey were specifically designed to probe this idea. The first of these, scenario 7 stated, "You introduce your unit on ecosystems by defining the terms the students need to know such as carnivore, herbivore, and omnivore." Participants reported that they would be less likely to teach science this way on their post-surveys $(Z=-10.09, p=<.001)$ than they did on the presurvey. This scenario described teaching science in a way potentially similar to what they experienced as learners of science (Banilower et al., 2013). However, teaching science in a way that begins with vocabulary and definitions does not fit with the idea of "experiences before explanations" as a guiding principle for science teaching that was introduced in the science methods course. Participants' views about the way they would teach science shifted towards alignment with visions of science teaching introduced during their science methods course.

Additionally, scenario 2 asked, "You are teaching a unit on the weather. You decided to have your class take pictures of the clouds in the sky and take daily weather measurements. As a class, you try to figure out if there are any patterns in the data." The majority ( $~ 80 \%)$ of participants indicated this as a way they would "definitely" teach science on the pre-survey. On the post survey this majority (90\%) was increased and there was also a significant shift towards this as a way they would "definitely" teach for those who selected either "sometimes" or "never" on the pre-survey $(Z=-2.59, \mathrm{p}=0.010)$. This scenario described teaching science in a way that fit with the idea that students should have experiences with scientific phenomena (e.g. weather and clouds) and then look for patterns in the data. For this scenario, many participants' views about this as a way they would teach science maintained alignment with visions of science teaching introduced as part of the science methods course and others shifted towards alignment with this vision.

These two scenarios are examples of ways in which participants' reported views of how to teach science shifted towards or maintained alignment with the principle of "experiences before explanations," which was a key idea introduced in their science methods course. Additional examples of alignment with this principle can be seen in participant responses to scenarios 6, 8, 15, and 18 (see Table 1).

Another key principle introduced in the science methods course was the importance of eliciting and building on elementary students' ideas throughout a science lesson (Windschitl et al., 2012). Additionally, the course instructor emphasized students' ideas as building blocks for scientific ideas as part of moving away from a tendency towards categorizing students' ideas as simply correct or incorrect (Campbell et al., 2016). Scenario 10 addressed this principle with, "You are teaching about the water cycle. You organize a time for a whole class discussion so that children can talk to each other about their ideas about condensation." There was a significant shift in participants' views of this towards a way in which they would teach science $(Z=-3.797$, $\mathrm{p}<0.001)$. This scenario described teaching science in a way that foregrounds students' ideas as an important part of the learning process. It also described a teaching practice known as a science talk (Gallas, 1995) that 
prospective teachers were introduced to as part of their science methods course. Additionally, by the end of the science methods course each of the prospective teachers planned and carried out a science talk in their field placement classrooms. Not all of the prospective teachers had a positive experience with this activity, which might account for some of the "sometimes" responses on the post-survey.

In the methods course, an overarching principle for teaching science was that teachers should engage students in the practices of science and engineering (National Research Council, 2012). The previous examples focused on principles that implicitly connected to this idea, but there were also scenarios that were more explicitly connected to one or more of the practices. One of these was scenario 8 which stated, "You give students batteries, bulbs and wires. You encourage the students to find all the possible ways to light the bulb. Students make arguments about how to light the bulb.” As in scenario 2, the majority (69\%) of participants identified this scenario as a way they would "definitely" teach science on the pre-survey and also had a significant shift toward "definitely" on the post-survey $(Z=-5.49, p<0.001)$. In this scenario, two elements aligned with big ideas from the science methods course. First, the scenario described teaching science in a way that began with student experiences, which fits with the "experiences before explanations" principle. Second, it explicitly included having students make arguments as part of the lesson. Making arguments from evidence is one of the practices of science and engineering. The science methods course emphasized engaging students in these practices as an important part of teaching science.

Scenario 15 asked, "You want students to learn the phases of the Moon. You have students use a light bulb and Styrofoam ball to model the Earth-Sun-Moon system." Participants indicated that this was a way that they would be more likely to teach science on the post surveys $(Z=-4.61, \mathrm{p}<0.001)$ than they did on the presurveys. This was another scenario that included one of the practices of science and engineering, "developing and using models," which was emphasized in the science methods course. Additionally, this was an activity that participants engaged in as part of the science methods course so they had first-hand experience with using a model like this to explore the phases of the Moon. Anecdotal evidence from this activity indicated that participants improved their own understanding of Moon phases through engagement in this activity, which may have provided additional support for their view of this as a productive way to teach science.

These two scenarios specifically addressed two of the practices of science and engineering-making arguments from evidence and developing and using models (National Research Council, 2012). The science methods course emphasized engaging students in these practices as an important part of teaching science. Participants shifted towards or maintained alignment with this as a way that they would teach science in the future.

Across the scenarios described above, participants' responses about how they would teach science shifted towards or remained aligned with key principles introduced as part of the science methods course they completed. This suggests that the science methods course had some influence on how these prospective elementary teachers thought about teaching science. The best example of the influence of the methods course on this shift may be found in scenario seven which flipped from being a way that $45 \%$ of participants would definitely teach science at the beginning of the semester to a way that $77 \%$ of participants would never teach science at the end of the semester. This shift might be attributable to the straightforward principle of "experiences before explanations" and the course instructor's position that providing definitions for vocabulary is part of explanations and therefore should not occur at the beginning of a science lesson. 
Table 1: Visions of Science Teaching Survey Results

\begin{tabular}{|c|c|c|c|c|c|c|c|c|c|}
\hline & \multirow{3}{*}{ Scenario } & \multicolumn{6}{|c|}{ I would teach like this... } & \multirow{3}{*}{$\mathrm{Z}^{\mathrm{a}}$} & \multirow{3}{*}{$\mathrm{p}$} \\
\hline & & \multicolumn{2}{|c|}{ Definitely } & \multicolumn{2}{|c|}{ Sometimes } & \multicolumn{2}{|c|}{ Never } & & \\
\hline & & Pre & Post & Pre & Post & Pre & Post & & \\
\hline 1 & $\begin{array}{l}\text { Each day during a unit on the solar system you read to the } \\
\text { class from a chapter book about the solar system. Then, you } \\
\text { ask students to write down three things they learned from the } \\
\text { reading. }\end{array}$ & 21 & 10 & 107 & 79 & 41 & 75 & -4.113 & $<0.001$ \\
\hline 2 & $\begin{array}{l}\text { You are teaching a unit on the weather. You decide to have } \\
\text { your class take pictures of the clouds in the sky and take daily } \\
\text { weather measurements. As a class, you try to figure out if there } \\
\text { are any patterns in the data. }\end{array}$ & 135 & 148 & 31 & 14 & 3 & 2 & -2.588 & 0.010 \\
\hline 3 & $\begin{array}{l}\text { You want to teach about insects. You decide the best way to do } \\
\text { this is to have children cut out a pattern of body parts and } \\
\text { assemble these into an insect that is put on the bulletin board. }\end{array}$ & 59 & 61 & 92 & 85 & 18 & 18 & -.429 & 0.668 \\
\hline 4 & $\begin{array}{l}\text { In a unit on animals, you have students observe earthworms } \\
\text { and generate questions about earthworm behavior. Each small } \\
\text { group designs and carries out their own experiment to test a } \\
\text { hypothesis related to the group's questions. }\end{array}$ & 138 & 146 & 28 & 16 & 3 & 2 & -1.677 & 0.093 \\
\hline 5 & $\begin{array}{l}\text { You teach a recycling unit by presenting interesting facts about } \\
\text { recycling to your students. }\end{array}$ & 29 & 11 & 98 & 73 & 42 & 80 & -5.208 & $<0.001$ \\
\hline 6 & $\begin{array}{l}\text { You set up learning centers for a unit on force and motion. } \\
\text { Using resource books from your school's library, you select a } \\
\text { variety of activities that look like fun and are easy to do. }\end{array}$ & 81 & 69 & 73 & 73 & 15 & 22 & -1.476 & 0.140 \\
\hline 7 & $\begin{array}{l}\text { You introduce your unit on ecosystems by defining the terms } \\
\text { that students need to know such as carnivore, herbivore, and } \\
\text { omnivore. }\end{array}$ & 77 & 13 & 79 & 24 & 13 & 127 & 10.085 & $<0.001$ \\
\hline
\end{tabular}




\begin{tabular}{|c|c|c|c|c|c|c|c|c|c|}
\hline & \multirow{3}{*}{ Scenario } & \multicolumn{6}{|c|}{ I would teach like this... } & \multirow{3}{*}{$\mathrm{Z}^{\mathrm{a}}$} & \multirow{3}{*}{$\mathrm{p}$} \\
\hline & & \multicolumn{2}{|c|}{ Definitely } & \multicolumn{2}{|c|}{ Sometimes } & \multicolumn{2}{|c|}{ Never } & & \\
\hline & & Pre & Post & Pre & Post & Pre & Post & & \\
\hline 8 & $\begin{array}{l}\text { You give students batteries, bulbs and wires. You encourage } \\
\text { the students to find all the possible ways to light the bulb. } \\
\text { Students make arguments about how to light the bulb. }\end{array}$ & 117 & 157 & 41 & 3 & 11 & 4 & -5.486 & $<0.001$ \\
\hline 9 & $\begin{array}{l}\text { When teaching about photosynthesis, you explain how } \\
\text { photosynthesis works, then you have your students write skits } \\
\text { and rap songs that explains how plants get their food. }\end{array}$ & 77 & 53 & 73 & 79 & 19 & 32 & -2.976 & 0.003 \\
\hline 10 & $\begin{array}{l}\text { You are teaching about the water cycle. You organize a time for } \\
\text { a whole class discussion so that children can talk to each other } \\
\text { about their ideas about condensation. }\end{array}$ & 73 & 104 & 82 & 52 & 14 & 8 & -3.797 & $<0.001$ \\
\hline 11 & $\begin{array}{l}\text { You want your students to understand how magnets work, so } \\
\text { you have them read an informational text about magnets to } \\
\text { each other and then answer questions together based on what } \\
\text { they read. }\end{array}$ & 6 & 3 & 75 & 34 & 88 & 127 & -4.817 & $<0.001$ \\
\hline 12 & $\begin{array}{l}\text { You want your students to understand how sound works. You } \\
\text { present a series of demonstrations that illustrate the } \\
\text { important concepts. }\end{array}$ & 70 & 74 & 91 & 72 & 8 & 17 & -.192 & 0.848 \\
\hline 13 & $\begin{array}{l}\text { You have some curriculum materials about seasons that } \\
\text { include student sheets with pictures of seasons. You have } \\
\text { students complete the worksheets to match the pictures with } \\
\text { the words. }\end{array}$ & 17 & 4 & 100 & 83 & 52 & 77 & -4.047 & $<0.001$ \\
\hline 14 & $\begin{array}{l}\text { Your students are studying solids and liquids. You have } \\
\text { students sort objects into different groups based on their } \\
\text { observable properties. }\end{array}$ & 107 & 104 & 61 & 55 & 1 & 4 & -.378 & 0.706 \\
\hline Jour & al of Educational Research and Practice & & & & & & 308 & & \\
\hline
\end{tabular}




\begin{tabular}{|c|c|c|c|c|c|c|c|c|c|}
\hline & \multirow{3}{*}{ Scenario } & \multicolumn{6}{|c|}{ I would teach like this... } & \multirow{3}{*}{$\mathrm{Z}^{\mathrm{a}}$} & \multirow{3}{*}{$\mathrm{p}$} \\
\hline & & \multicolumn{2}{|c|}{ Definitely } & \multicolumn{2}{|c|}{ Sometimes } & \multicolumn{2}{|c|}{ Never } & & \\
\hline & & Pre & Post & Pre & Post & Pre & Post & & \\
\hline 15 & $\begin{array}{l}\text { You want students to learn the phases of the Moon. You have } \\
\text { students use a light bulb and Styrofoam ball to model the } \\
\text { Earth-Sun-Moon system. }\end{array}$ & 127 & 153 & 39 & 10 & 3 & 1 & -4.611 & $<0.001$ \\
\hline 16 & $\begin{array}{l}\text { During a unit on electricity, your students want to figure out } \\
\text { how to set up a telegraph between two classrooms. You and } \\
\text { your students spend } 2 \text { days designing and testing a telegraph } \\
\text { system. }\end{array}$ & 110 & 139 & 48 & 19 & 11 & 6 & -4.307 & $<0.001$ \\
\hline 17 & $\begin{array}{l}\text { For the school science fair, you provide your students with } \\
\text { directions for possible projects they could do. }\end{array}$ & 63 & 26 & 79 & 85 & 27 & 52 & -5.010 & $<0.001$ \\
\hline 18 & $\begin{array}{l}\text { Your students wonder why some trees in the schoolyard are } \\
\text { dying and others are not. You decide to make this the focus of } \\
\text { a whole class investigation. You have students look for } \\
\text { evidence for what is happening to the trees. }\end{array}$ & 130 & 155 & 37 & 8 & 2 & 1 & -4.413 & $<0.001$ \\
\hline 19 & $\begin{array}{l}\text { Your school has a large natural area on the school grounds. } \\
\text { You take students out to look for insects. }\end{array}$ & 92 & 107 & 58 & 49 & 19 & 8 & -2.627 & 0.009 \\
\hline 20 & $\begin{array}{l}\text { Your class is studying structure and function. You decide to } \\
\text { have snails pull washers across the desks to see how much } \\
\text { weight a snail can pull. }\end{array}$ & 51 & 75 & 47 & 49 & 71 & 40 & -4.016 & $<0.001$ \\
\hline
\end{tabular}

${ }^{\mathrm{a}} \mathrm{Z}$ is computed from the Wilcoxon signed-rank test 
Canipe \& Coronado Verdugo, 2020

\section{Meaningful Science Methods Course Experiences}

We conducted follow-up interviews with selected participants and used these interviews to provide deeper understandings about the shifts in their visions of science teaching measured by the survey. In this section, we present themes that arose during these interviews about which experiences participants perceived as particularly meaningful.

\section{Model Science Activities}

During the follow-up interviews, we asked participants about experiences during the science methods course that they felt were particularly meaningful for how they thought about teaching science. In response to this question, Hannah, one of the participants replied, "[the instructor taught] us how to teach kids by doing some things with us, and then explaining why it would be meaningful for the students." In her response, Hannah identified two key aspects of the science methods course that she found to be particularly meaningful. The first of these was engaging in activities like those she might teach to her own future elementary students. Then Hannah also identified the explanations provided by the course instructor (first author of this paper) about how these activities and the way they were structured would be meaningful to elementary students as another meaningful aspect of the course from her perspective.

When asked the same question about which activities were most meaningful, another participant, Taylor, replied, "[We] actually do the experiments..., as if we were students, so that way we would like have an idea about how to do it in our own classroom, cause I really respond like to model teaching." Similar to Hannah, Taylor identified participating in activities in the role of an elementary student as a particularly meaningful experience during the science methods course. She went on to explain that this was meaningful to her because it provided a model of teaching that she could use when thinking about how to teach science in her own future classroom. Hannah and Taylor both identified the model elementary science lessons that they participated in as part of the science methods course as particularly meaningful experiences. They then explained that these were meaningful because of the process of modeling as well as the way in which the course instructor explained how the lessons would be meaningful learning experiences for students.

During the follow-up interviews, we also asked participants about scenarios from the Visions of Science Teaching survey in which they shifted their responses from never to definitely or vice versa in terms of whether the scenario was a way they would teach science. Emily was asked about this scenario, "You want your students to understand how sound works. You present a series of demonstrations that illustrate the important concepts," for which her response shifted from never to definitely. In explaining why her response shifted, Emily said,

I think, when I first answer[ed] that, I didn't really understand how I would teach that, so I kind of say never, because I was, "I don't understand how I'd do that." And then, when we did that thing in... class with all the different sounds and like the drum and stuff, that kind of gave me ways to think about how I could teach it differently... um so, I think in the beginning it was more just like, I don't really know how I would do this, so I would never teach it, but like, since [I saw] ways that like we would be able to teach it, then I think now I would be a lot more confident teaching something like that.

For Emily, experiencing a lesson about sound designed for elementary students as part of her methods course helped her see how she could teach about sound in a similar way. This was meaningful for her because it provided a teaching model, which helped her see how she could teach something that at the beginning of the semester she did not understand how she would teach to her future students.

Prospective teachers perceived the model science lessons as a critical element of the science methods course in terms of influencing their visions of teaching science. Almost $70 \%$ of the prospective teachers who 
participated in the interviews mentioned these model activities as things that influenced their visions of teaching science.

\section{Connecting Course Activities to How Students Learn Science}

In addition to describing class activities as a meaningful part of the science methods course, participants also shared other aspects of the course in response to the question about which activities in the science methods course were particularly meaningful to their vision of themselves as science teachers. One participant, Alexis, responded to the question about meaningful experiences in this way, "giving us like the background on how students learn science and what would be most effective for them, um, really helped me." Here Alexis identified learning about the principles related to how elementary students learn science as a meaningful part of the science methods course. She went on to connect this to an understanding of teaching methods or activities that would then be effective in supporting elementary students learning about science.

Hannah also referenced the idea of understanding how elementary students learn science when she described learning "why it (a science activity during the methods course) would be meaningful for the students." Both Alexis and Hannah described learning about how elementary students learned science as a meaningful part of the science methods course for them. Hannah linked this understanding directly to the model science activities that were part of the course while Alexis was more specific about learning not only how students learn science, but also what would be most effective in supporting this learning for her future students.

During the science methods course prospective teachers watched and analyzed videos of science teaching in elementary classrooms. These videos provided another type of modeling for effective science teaching practices. In her follow-up interview, Katherine spoke about how the videos helped her think about teaching science:

Watching the videos really helped me because of the way that I learn it was um it made a lot more sense to me if I could see you know see how it worked in the classroom and what the processes that the teachers went through and you know how kids reacted... but seeing it seeing it always helps me so I would say that's probably that helps me.

For Katherine, seeing how science activities worked in a classroom with children was a powerful model that supported her own learning about how to teach science.

Approximately 55\% of prospective teachers who participated in the follow-up interviews mentioned connections between course activities and how students learned science as influential experiences.

\section{Discussion}

Science methods courses are designed to prepare prospective teachers to teach science in ways that reflect current understandings about science teaching and learning. Teacher educators and prospective teachers may face challenges for a variety of reasons including the past experiences of prospective teachers as science learners themselves. Previous research (Bleicher \& Lindgren, 2005; Murphy \& Smith, 2012; Palmer, 2006; Tosun, 2000a; Varma et al., 2009) showed that these past experiences can be powerful influences on prospective teachers' beliefs about teaching science. However, these beliefs are not resistant to change (Soysal \& Radmard, 2018; Wall, 2016).

In this study we showed that prospective teachers' visions of science teaching not only shifted towards or maintained alignment with the way science teaching was presented in a science methods course, but they also identified certain aspects of the course as particularly influential. The quantitative results show that scenarios 
that were explicitly connected to straightforward principles from the methods course were those that showed the most change towards alignment with ideas from the methods course.

\section{Using Straightforward Principles}

The methods course was designed with a number of principles of good science teaching embedded throughout the semester. However, some of these principles (e.g. providing experiences before explanations) were less complex than others in terms of how they could be implemented in a classroom. This particular principle was presented by the course instructor (first author) as the key takeaway for the course. The scenario that showed the biggest shift between the pre- and post-Visions of Science Teaching surveys was one that represented a very explicit application of this principle. This scenario described beginning a unit by defining the key science vocabulary terms that students would need to know. During the course, providing definitions for vocabulary terms was emphasized as an example of explanations that should occur after students have experiences with the scientific phenomena. Therefore, this particular scenario represented a situation that was explicitly addressed so it is not surprising that this scenario showed a significant shift from the beginning to the end of the course.

However, in addition to this scenario explicitly connected to a course principle, other scenarios that connected less explicitly to course principles also showed shifts towards alignments with these principles. For example, the scenario that described having students make daily observations of weather and look for patterns was another in which the shift towards this as a way participants would definitely teach science in the future. This scenario also embodied the straightforward principle of providing students with experiences before explanations, but in a less explicit way than the scenario involving pre-teaching vocabulary. Even so, the prospective teachers still showed a shift towards alignment with this type of teaching. These findings support the idea that using straightforward principles as foundations of science methods courses may have the potential to significantly shift prospective elementary teachers' views of teaching science.

\section{Modeling and Unpacking}

In addition to introducing straightforward principles of science teaching, another finding of our study supported the powerful influence of model science lessons that embodied those practices. A majority of participants cited these model activities as something from the methods course that they perceived as influential to their thinking about how to teach science. This finding supports previous work that emphasizes the importance of modeling in teacher education (McGrew et al., 2018). The importance of model activities was also seen in the Visions of Science Teaching Survey where the scenario about learning the phases of the Moon showed a significant shift towards a way that participants would definitely teach science. This particular activity was used as a model activity in the science methods course, which may have influenced participants' views on this as a way to teach science.

In addition to the model activities themselves, the interviews supported the idea that modeling activities were particularly influential when the teacher educator unpacked the relationship between the structure of the model activity and student learning. This finding supports the advice that when teacher educators use modeling in methods courses that they not only demonstrate appropriate pedagogical moves, but that they also explain the pedagogical reasoning behind those moves (McGrew et al., 2018).

\section{Implications and Conclusion}

This study offers support for the idea that science methods courses can be influential in terms of how prospective elementary teachers see themselves as teachers of science and identifies experiences that they perceive as particularly influential. Therefore, elementary science teacher educators should consider 
implementing strategies in their courses such as straightforward principles of teaching science that novice teachers can easily apply. Additionally, the use of pedagogical models with accompanying explanations of the reasoning behind particular pedagogical moves is another important approach that elementary science teacher educators should consider employing as part of their methods course.

While this study demonstrated that prospective elementary teachers' visions of themselves as science teachers became more aligned with or maintained alignment with principles espoused in their methods courses, the study did not follow these teachers into their beginning practice. This is an important avenue for future research in order to determine the extent to which these visions are put into practice after prospective teachers complete their teacher education program and move into their own classrooms. Further research might also examine how the principles from the methods course are reflected in other assignments from the methods course (i.e. unit and lesson plans). While examining these course artifacts would not show whether the prospective teachers enact the principles, they could provide insights beyond what is available from the survey data used in this study.

This study added further support to the idea that science methods courses provide teacher educators with a valuable opportunity to influence how prospective elementary teachers envision themselves and develop identities as science teachers. Given the influence that identity has on how an individual understands what it means to be a teacher and how they act as a teacher, it is imperative that science teacher educators and science education researchers work together to understand and develop effective science methods courses for prospective elementary teachers. 


\section{References}

Avraamidou, L., \& Zembal-Saul, C. (2010). In search of well-started beginning science teachers: Insights from two first-year elementary teachers. Journal of Research in Science Teaching, 47(6), 661-686. https://doi.org/10.1002/tea.20359

Banilower, E. R. (2019). Understanding the big picture for science teacher education: The 2018 NSSME+. Journal of Science Teacher Education, 30(3), 201-208. https://doi.org/10.1080/1046560X.2019.1591920

Banilower, E. R., Smith, P. S., Weiss, I. R., Malzahn, K. A., Campbell, K. M., \& Weis, A. M. (2013). Report of the 2012 national survey of science and mathematics education. Horizon Research, Chapel Hill, NC. http://www.nnstoy.org/download/stem/2012\%20NSSME\%20Full\%20Report.pdf

Blackmore, K., Howard, C., \& Kington, A. (2018). Trainee teachers' experience of primary science teaching, and the perceived impact on their developing professional identity. European Journal of Teacher Education, 41(4), 529-548. https://doi.org/10.1080/02619768.2018.1462330

Blank, R. K. (2013). Science instructional time is declining in elementary schools: What are the implications for student achievement and closing the gap? Science Education, 97(6), 830-847. https://doi.org/10.1002/sce.21078

Bleicher, R. E., \& Lindgren, J. (2005). Success in science learning and preservice science teaching selfefficacy. Journal of Science Teacher Education, 16(3), 205-225. https://doi.org/10.1007/s10972005-4861-1

Boyer, E. (2016). Preservice elementary teachers' instructional practices and the teaching science as argument framework. Science \& Education, 25(9-10), 1011-1047. https://doi.org/10.1007/s11191-016-9864-0

Campbell, T., Schwarz, C., \& Windschitl, M. (2016). What we call misconceptions may be necessary steppingstones toward making sense of the world. Science \& Children, 53(7), 28-33.

Canipe, M. M. (2016). Preservice elementary teachers' actual and designated identities as teachers of science and teachers of students [Doctoral dissertation, The University of Arizona]. https://repository.arizona.edu/handle/10150/612575

Creswell, J. W., \& Clark, V. L. P. (2017). Designing and conducting mixed methods research (3rd ed.). SAGE Publications, Inc.

Davis, E. A., Petish, D., \& Smithey, J. (2006). Challenges new science teachers face. Review of Educational Research, 76(4), 607-651. https://doi.org/10.3102/00346543076004607

Emerson, R. M., Fretz, R. I., \& Shaw, L. L. (1995). Writing ethnographic fieldnotes. University of Chicago Press.

Floden, R. E., Richmond, G., \& Salazar, M. (2020). A nation at risk or a nation in progress? Naming the way forward through research in teacher education. Journal of Teacher Education, 71(2), 169-171. https://doi.org/10.1177/0022487119900628

Friedrichsen, P., \& Dana, T. (2003). Using a card-sorting task to elicit and clarify science-teaching orientations. Journal of Science Teacher Education, 14(4), 291-309. http://www.jstor.org/stable/43156324

Gallas, K. (1995). Talking their way into science: Hearing children's questions and theories, responding with curricula. Teachers College Press.

Gonzalez, N., Moll, L. C., \& Amanti, C. (Eds.). (2005). Funds of knowledge: Theorizing practices in households, communities, and classrooms. Lawrence Erlbaum Associates. 
Gunckel, K. L. (2010). Experiences, patterns, and explanations. Science \& Children, 48(1), 46-49.

Gunckel, K. L. (2011). Mediators of a preservice teacher's use of the Inquiry-Application Instructional Model. Journal of Science Teacher Education, 22(1), 79-100. https://doi.org/10.1007/s10972-010-9223-y

Haefner, L. A., \& Zembal-Saul, C. (2004). Learning by doing? Prospective elementary teachers' developing understandings of scientific inquiry and science teaching and learning. International Journal of Science Education, 26(13), 1653-1674. https://doi.org/10.1080/0950069042000230709

Luehmann, A. L. (2007). Identity development as a lens to science teacher preparation. Science Education, 91(5), 822-839. https://doi.org/10.1002/sce.20209

Marshall, C., \& Rossman, G. B. (2010). Designing qualitative research (5th ed.). Sage Publications, Inc.

McGrew, S., Alston, C. L., \& Fogo, B. (2018). Modeling as an example of representation. In P. Grossman (Ed.), Teaching core practices in teacher education (pp. 35-55). Harvard Education Press.

Murphy, C., \& Smith, G. (2012). The impact of a curriculum course on pre-service primary teachers' science content knowledge and attitudes towards teaching science. Irish Educational Studies, 31(1), 77-95. https://doi.org/10.1080/03323315.2011.634061

National Research Council. (2007). Taking science to school: Learning and teaching science in grades K-8 (R. A. Duschl, H. A. Schweingruber, \& A. W. Shouse, Eds.). National Academies Press. https://doi.org/10.17226/11625

National Research Council. (2012). A framework for K-12 science education practices, crosscutting concepts, and core ideas. National Academies Press.

Palmer, D. (2006). Durability of changes in self-efficacy of preservice primary teachers. International Journal of Science Education, 28(6), 655-671. https://doi.org/10.1080/09500690500404599

Plumley, C. L. (2019). 2018 NSSME+: Status of elementary school science. Horizon Research, Inc.

Richmond, G., Floden, R. E., \& Drake, C. (2018). Research that illuminates enduring dilemmas in teacher education. Journal of Teacher Education, 69(4), 327-329.

https://doi.org/10.1177/0022487118786735

Sachs, J. (2005). Teacher education and the development of professional identity: Learning to be a teacher. In P. Denicolo \& M. Kompf (Eds.), Connecting policy and practice: Challenges for teaching and learning in schools and universities (pp. 5-21). Routledge.

Saldaña, J. (2016). The coding manual for qualitative researchers (3rd. ed.). Sage Publications.

Schneider, J. (2018). Marching forward, marching in circles: A history of problems and dilemmas in teacher preparation. Journal of Teacher Education, 69(4), 330-340.

https://doi.org/10.1177/0022487117742904

Schwarz, C. V., Gunckel, K. L., Smith, E. L., Covitt, B. A., Bae, M., Enfield, M., \& Tsurusaki, B. K. (2008). Helping elementary preservice teachers learn to use curriculum materials for effective science teaching. Science Education, 92(2), 345-377. https://doi.org/10.1002/sce.20243

Settlage, J., Southerland, S. A., Smith, L. K., \& Ceglie, R. (2009). Constructing a doubt-free teaching self: Selfefficacy, teacher identity, and science instruction within diverse settings. Journal of Research in Science Teaching, 46(1), 102-125. https://doi.org/10.1002/tea.20268

Smith, R. G. (2007). Developing professional identities and knowledge: Becoming primary teachers. Teachers and Teaching, 13(4), 377-397. https://doi.org/10.1080/13540600701391937 
Soysal, Y., \& Radmard, S. (2018). Social negotiations of meanings and changes in the beliefs of prospective teachers: A Vygotskian perspective. Educational Studies, 44(1), 57-80. https://doi.org/10.1080/03055698.2017.1345676

Tosun, T. (2000a). The impact of prior science course experience and achievement on the science teaching self-efficacy of preservice elementary teachers. Journal of Elementary Science Education, 12(2), 2131. https://doi.org/10.1007/BF03173597

Tosun, T. (2000b). The beliefs of preservice elementary teachers toward science and science teaching. School Science and Mathematics, 100(7), 374-379. https://doi.org/10.1111/j.1949-8594.2000.tb18179.x

Varma, T., Volkmann, M., \& Hanuscin, D. (2009). Preservice elementary teachers' perceptions of their understanding of inquiry and inquiry-based science pedagogy: Influence of an elementary science education methods course and a science field experience. Journal of Elementary Science Education, 21(4), 1-22. https://doi.org/10.1007/BFo3182354

Wall, C. R. G. (2016). From student to teacher: Changes in preservice teacher educational beliefs throughout the learning-to-teach journey. Teacher Development, 20(3), 364-379. https://doi.org/10.1080/13664530.2016.1149509

Windschitl, M., Thompson, J., Braaten, M., \& Stroupe, D. (2012). Proposing a core set of instructional practices and tools for teachers of science. Science Education, 96(5), 878-903. https://doi.org/10.1002/sce.21027

Woolson, R. F. (2008). Wilcoxon signed-rank test. In Wiley encyclopedia of clinical trials (pp. 1-3). American Cancer Society. https://doi.org/10.s1002/9780471462422.eoct979

Zembal-Saul, C., McNeill, K. L., \& Hershberger, K. (2013). What's your evidence?: Engaging K-5 students in constructing explanations in science. Pearson.

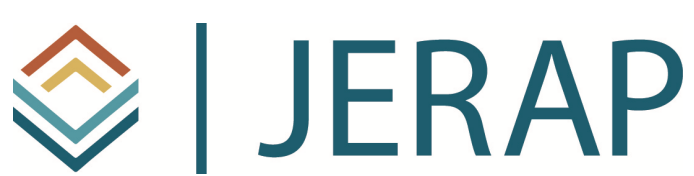

The Journal of Educational Research and Practice is a peerreviewed journal that provides a forum for studies and dialogue about developments and change in the field of education and learning. The journal includes research and related content that examine current relevant educational issues and processes. The aim is to provide readers with knowledge and with strategies to use that knowledge in educational or learning environments. JERAP focuses on education at all levels and in any setting, and includes peer-reviewed research reports, commentaries, book reviews, interviews of prominent individuals, and reports about educational practice. The journal is sponsored by the Richard W. Riley College of Education and Leadership at Walden University, and publication in JERAP is always free to authors and readers. 